https://doi.org/10.46344/JBINO.2020.v09i05.21

\title{
STUDY OF SHATAVARI IN AMLAPITTA
}

Dr.Shyamal P. Nirmal

Associate Professor, Rasashastra \& Bhishajya Kalpana, Ashvin Rural Ayurved College, Manchihill

(Received on Date: $8^{\text {th }}$ August 2020

Date of Acceptance: $11^{\text {th }}$ August 2020

Date of Publish: $4^{\text {th }}$ September 2020)

Email id - shyamalpnirmal@gmail.com

\begin{abstract}
Amlapitta as per Ayurveda is a disease in which excessive secretion of Amla Guna of Pitta takes place causing symptoms like burning sensation. Though there are many opinions regarding Modern interpretation of Amlapitta, specifically it can be correlate with Gastritis.In the present article we are discussing regarding the study of shatvari in amlapitta.
\end{abstract}

Keywords: Shatvari, Amlapitta etc.

No: of References: 05 


\section{INTRODUCTION}

Hyperacidity(Amlapitta) is one of the most common disease seen in the society. It is seen in all ages, all classes, and all community. Hyperacidity refers to a set of symptoms caused by an imbalance between the acid secreting mechanism of the stomach and proximal intestine and the protective mechanisms that ensure their safety. The stomach normally secretes acid that is essential in the digestive process. When there is excess production of acid in the stomach, it results in the condition known as acidity. Amlapitta is the disease of Annavaha strotasa or G.I. tract which is classified according to pravrutti into 2 catagories viz- Urdhwaga and Adhoga. In the present manuscript we are discussing regarding study of shatvari against amla pitta.

\section{AYURVEDIC TREATMENT FOR AMLAPITTA:}

The main key for treating Amlapitta is to improve digestion. As the saying goes "Prevention is better than cure" it is better to avoid all the causative factors of Amla-pitta. One should follow the meal times. Avoid eating spicy foods, or foods containing excess amount of garlic, salt, oil, chillies, etc. very often. Include liquids like kokam juice, sweetlime juice, pomogranate juice, amla juice. Shatavari kalpa mixed with water. Medicated water. with ushir (wala) or coriander seeds, or laja (puffed rice). Shadangodak (water medicated with musta, parpatak, ushir, chandan, udichya \& shunti). Moramla (jam of amla), gulkand (jam of rose petals) can be taken singly or along with milk gives good relief, dadimpak (sweet syrup of pomogranate juice). Vegetables like white pumpkin, bitter gourd, okra, all leafy vegetables can be eaten except methi which should be definitely avoided. Fruits like black grapes, sweet lime, pomogranate, fig, dry fig, black resins.

\section{What is Shatvari}

Shatavari is a perennial much branched climbing herb found all over India, especially in tropical and sub-tropical parts and in Himalayan region upto $1400 \mathrm{~m}$. elevation. It is also cultivated. The fleshy root of shatavari has been used as one of the most powerful nutritive and spermatogenic herb in Ayurvedic system of medicine. Botanical Name : Asparagus racemosus Family : (Liliaceae (Rasonakula) Vernacular Names: Oriya : Shatabari Hindi : Satavar Bengali : Shatamooli Marathi : Shatavari Gujarati : Shatawari Telugu : Challan gadda Tamil : Sadawari Kannada : Majjigegade

\section{Shatavari and its role in Amla Pitta.}

Shatavari is used in Ayurveda to balance pitta and vata, but can increase kapha due to its heavy nature. Its bitter and sweet taste has a cooling effect on the system, and its unctuous (oily), building nature makes it a great support for anyone looking for a nourishing, grounding effect. 1 These combined qualities make it a rasayana (rejuvenative) for the reproductive system (particularly female), 
the digestive system (particularly when pitta is involved), and for the blood. 3

\section{USAGE OF SHATVARI}

Ayurveda prefers the powder form of herbs because tasting the herb starts the digestive process and sends signals to the body to initiate the body's own supportive mechanisms. Shatavari powder (about $1 / 4$ to $1 / 2$ teaspoon for starters) is traditionally taken mixed in a glass of warm milk, with honey, or sugar (sucanat) if desired. It can also be mixed with ghee, or actually cooked into an herbalized ghee, to reap its building and nourishing benefits. 4 Shatavari tablets can be easier to use for those who desire the convenience of a tablet (traveling, on the go, at the office), or do not like the taste of the powder. You can still follow the tablets with a glass of warm milk if desired, or take with warm water. Liquid extract is also available and provides an alternative method of taking shatavari. It's convenient, easy to assimilate, and has a long shelf life. Banyan Botanicals prefers tablets over capsules as there is still some mild tasting of the herb that occurs. Taste starts the digestive process, and sends signals to the body as to what to expect, already initiating your body's own inner pharmacy.

\section{DISCUSSION on theraptic properties of Shatvari.}

Shatavari (Asparague racemosus) root and their different extracts have shown alterative, demulcent,aphrodisiac, antiseptic and anti-cancer activity. It also acts as a nutritive tonic. Shatavari also contains a saponingly coside that exhibits antioxytocic activity. It is a good source of folic acid, that is vital for foetal neuronal growth and blood formation. Therapeutic Uses : The roots of asparagus racemosus (Shatavari) has been used for ages in Ayurvedic medicine and other traditional medicines as follows: $\ddagger$ In the treatment of general debility, male infertility (due to low sperm count), loss of libido, epilepsy (fits), mental debility and in many male diseases. $\ddagger$ In case of female oriented ailments such as menopausal syndrome, anaemia, lower quantity of breast milk secretion, and for both mental and physical ailments, the roots of Asparagus racemosus has been proved its medicinal efficacy. Above all, the root of Asparagus racemosus (Shatavari) is a well-known nutritive, aphrodisiae, astringent medicine for all age groups having no side effects or any contra-indication. Effects on Digestive System : For relieving pain and discomfort caused by acrid matter in the stomach, it is wonderful. It seems to remove the irritating effects of acids in a better way than alkalies, it is used as a mild laxative.

\section{REFERENCES:}

Khulbe A. Asparagus racemosus (shatavari): a multipurpose plant

Vaidy SS, Dole VA. Bhaishajya Kalpana Pratykshika, Anamol Publication, Pune. Reprit 2004, p.40

Acharya YT. Sushruta Samhita, Chikitsa Sthana, 10/12, Chaukhambha krishanadas academy; Varanasi: Reprint 2004.p.415. 
Pharmacognosy, Kokate CK et.al. (Eds), 2nd Ed. 1994; Nirali Prakashan (Pune, India) pp : 625- 629 .

KM. Nadkarni's Indian Materia Medica. 3rd Ed. Vol.1, 1976; Popular Prakashan (Mumbai) pp.1292-1294
Research Drugs and Pharmaceuticals (Guj) Pvt. Ltd. Therapeutic Index, page.6-7

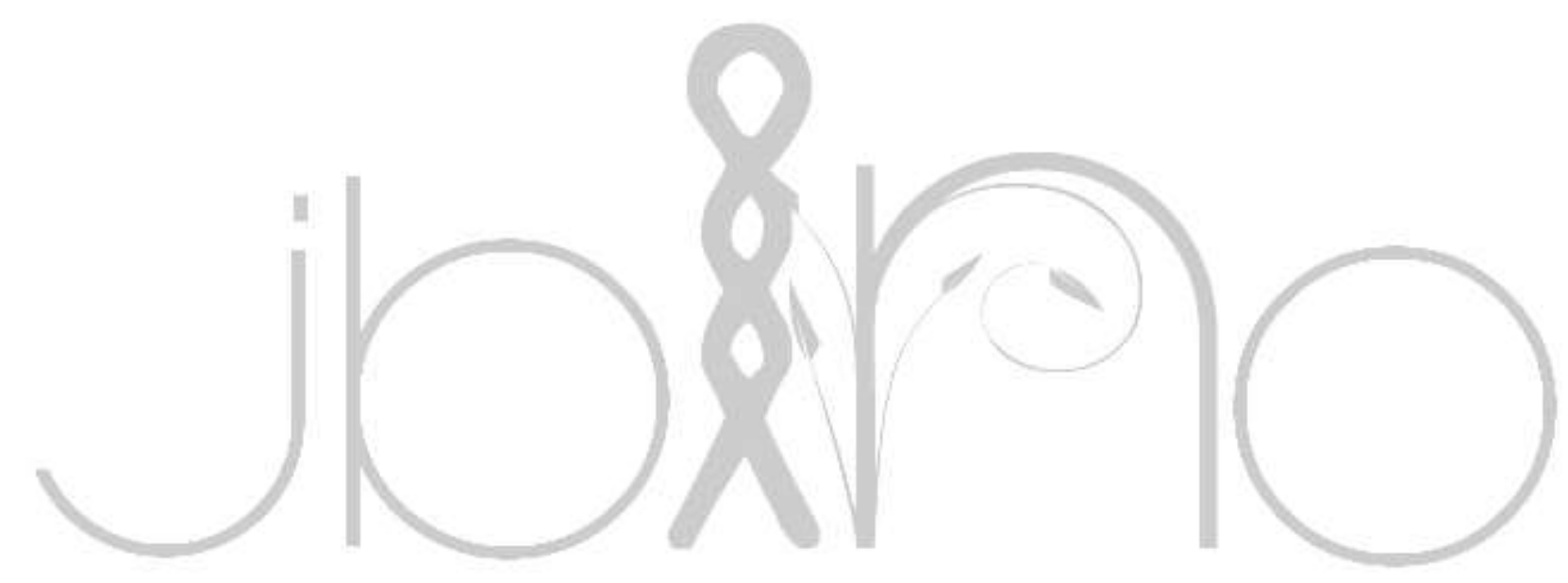

